\title{
Sites for the selective hydrogenation of ethyne to ethene on supported $\mathrm{NiO} / \mathrm{Au}$ catalysts
}

\author{
S. A. Nikolaev • D. A. Pichugina • D. F. Mukhamedzyanova
}

Published online: 15 September 2012

(C) The Author (s) 2012. This article is published with open access at SpringerLink.com

\begin{abstract}
Au}, \mathrm{NiO}$, and $\mathrm{NiO} / \mathrm{Au}$ clusters of $2.5-16 \mathrm{~nm}$, supported on $\mathrm{Al}_{2} \mathrm{O}_{3}, \mathrm{ZrO}_{2}, \mathrm{TiO}_{2}$, and $\mathrm{ZnO}$, were studied in the purification of ethene feedstock from ethyne by hydrogenation at $357 \mathrm{~K}$. The $\mathrm{Au}, \mathrm{NiO}$, and $\mathrm{NiO} / \mathrm{Au}$ catalysts possessed $100 \%$ selectivity to ethene. As the size of $\mathrm{NiO}$ clusters decreased from 7 to $3 \mathrm{~nm}$, the turnover frequency (TOF) decreased from $812-1,023$ to $276 \mathrm{~h}^{-1}$. In contrast with $\mathrm{NiO}, \mathrm{Au}$ activity increased with decreasing particle size. $\mathrm{NiO} / \mathrm{Au}$ catalysts possessed higher stability and activity in comparison with $\mathrm{Au}$ and $\mathrm{NiO}$ catalysts. The synergistic gain on $\mathrm{NiO} / \mathrm{Au}$ clusters (SG) calculated as $\mathrm{TOF}_{\mathrm{NiO} / \mathrm{Au}}-$ $\mathrm{TOF}_{\mathrm{Au}}-\mathrm{TOF}_{\mathrm{NiO}}$ was 1,$466 ; 1,147 ; 563$; and $569 \mathrm{~h}^{-1}$ for $\mathrm{NiO} / \mathrm{Au} / \mathrm{Al}_{2} \mathrm{O}_{3}, \mathrm{NiO} / \mathrm{Au} / \mathrm{TiO}_{2}, \mathrm{NiO} / \mathrm{Au} / \mathrm{ZnO}$, and $\mathrm{NiO} / \mathrm{Au} /$ $\mathrm{ZrO}_{2}$, respectively. The reasons of the observed catalytic trends and the origin of the most active and selective sites are discussed.
\end{abstract}

Keywords Synergism - Ethyne hydrogenation - DFT · $\mathrm{NiO} / \mathrm{Au} \cdot \mathrm{Au} \cdot$ Heat of adsorption

\section{Introduction}

Ethene feedstock for polymerization coming from the stage of hydrocarbons cracking contains $0.5-3 \%$ of ethyne compounds $[1,2]$. Even such a small content of ethyne impurities quickly poisons Ziegler-Natta polymerization catalysts $[2,3]$. Thus, preliminary removal of alkynes via hydrogenation is necessary [1-4]. Traditionally, the $\mathrm{Ag} / \mathrm{Pd}$ catalysts

S. A. Nikolaev $(\bowtie) \cdot$ D. A. Pichugina $\cdot$ D. F. Mukhamedzyanova Department of Chemistry, M.V. Lomonosov Moscow State University,

1 Leninskie Gory,

119991, Moscow, Russia

e-mail: serge2000@rambler.ru
HO-21 (BASF), G-58, and G-83 (Süd-Chemie) are employed for the hydrogenation of $\mathrm{C} \equiv \mathrm{C}$ bond to $\mathrm{C}=\mathrm{C}$ bond. However, turnover frequency (TOF) and stability of $\mathrm{Ag} / \mathrm{Pd}$ catalysts are often low. Moreover, undesirable "green-oil" and ethane by-products are usually formed on palladium surface $[3,4]$. Nowadays, the studies directed to improving of catalytic properties of palladium-based catalysts are becoming less popular, giving way to the intensive searching for alternative and high-performance palladium-free catalysts for the ethyne hydrogenation [1-5].

Nano-sized gold is an effective catalyst for oxidation [6], isomerization [7], cyclization [8], hydrodechlorination [9], and other reactions $[10,11]$. Composites based on bare gold clusters demonstrate high activity and/or selectivity in hydrogenation of 1,3-butadiene [2], 1-propyne [12], and ethynylbenzene [13] under the mild conditions. Bimetallic goldnickel catalysts also may possess the enhanced catalytic properties in conversion of different hydrocarbons: $n$-butane [14], allylbenzene [5, 7], and 2,4-dichloropfenol [9]. Thus, the application of gold and gold-nickel clusters in selective hydrogenation is very promising.

This work is an extension of studies of the catalytic properties of $\mathrm{Au}$ and $\mathrm{NiO} / \mathrm{Au}$ clusters in the hydrogenation of ethyne derivatives $[13,15]$. It was reported that $\mathrm{Au} / \mathrm{Al}_{2} \mathrm{O}_{3}$ catalysts possess high activity (up to $0.142 \mathrm{~s}^{-1}$ ) in the hydrogenation of ethynylbenzene into styrene at $423 \mathrm{~K}$. A synergistic effect was revealed for $\mathrm{NiO} / \mathrm{Au} / \mathrm{Al}_{2} \mathrm{O}_{3}$ in the hydrogenation of ethyne into ethene [15]: The conversion of ethyne on the $\mathrm{NiO} / \mathrm{Au}$ catalysts was higher than the sum of conversions on $\mathrm{Au}$ and $\mathrm{Ni}$ catalysts. It was found that synergistic gain on $\mathrm{NiO} / \mathrm{Au}$ clusters was maximized at $357 \mathrm{~K}$, and $\mathrm{Au} / \mathrm{Ni}$ ratio equaled 1:1 [15]. According to the analysis of oxidation state of metals in gold-contained catalysts [7], it was proposed that synergistic effect could be caused by the formation of new $\mathrm{Au}^{\delta+}$ catalytic sites. The 
goals of the present research were: (1) to study the regularities of catalytic action of $\mathrm{Au}$ and $\mathrm{NiO} / \mathrm{Au}$ clusters $(\mathrm{Au} /$ $\mathrm{Ni}=1: 1$ ), supported on $\mathrm{Al}_{2} \mathrm{O}_{3}, \mathrm{TiO}_{2}, \mathrm{ZrO}_{2}$, and $\mathrm{ZnO}$, in the hydrogenation of ethyne-ethene mixture at $357 \mathrm{~K}$; (2) to study the impact of clusters shape and size to the catalysis by gold, and (3) to determine the origin of the active gold sites by density functional theory (DFT).

\section{Experimental}

$\mathrm{Al}_{2} \mathrm{O}_{3}$ ("Katalizator," AOK-63-11) with a $160 \mathrm{~m}^{2} / \mathrm{g}$ surface area and an isoelectric point (IEP) equal to 7.0, $\mathrm{TiO}_{2}$ ("Degussa," Aerolyst ${ }^{\circledR} 7710,50 \mathrm{~m}^{2} / \mathrm{g}, 6.0$ IEP), $\mathrm{ZrO}_{2}$ (Degussa, Aerolyst ${ }^{\circledR} 6100,30 \mathrm{~m}^{2} / \mathrm{g}, 4.5$ IEP), and $\mathrm{ZnO}$ (Degussa, Aerolyst ${ }^{\circledR} 9000,36 \mathrm{~m}^{2} / \mathrm{g}, 10.0$ IEP) were used as the supports for metal clusters. Au/supports and $\mathrm{Pd} /$ $\mathrm{Al}_{2} \mathrm{O}_{3}$ were produced by deposition-precipitation $[15,16]$. In typical synthesis, $50 \mathrm{ml}$ of the aqueous solution of $\mathrm{HAuCl}_{4}$ (or $\mathrm{PdCl}_{2}$ ) with $5.8 \times 10^{-6} \mathrm{~g} / \mathrm{ml}$ metal content was adjusted to $\mathrm{pH}$ equal to the IEP of the support by adding the aqueous solution of $\mathrm{NaOH}(0.1 \mathrm{M})$. Then $1 \mathrm{~g}$ of the support was dispersed in the solution with stirring for $1 \mathrm{~h}$ at $307 \mathrm{~K}$. The precursor obtained was washed to remove $\mathrm{NaCl}$. The degree of $\mathrm{NaCl}$ removing was controlled via $\mathrm{AgNO}_{3}$ test. Then the sample was dried for $24 \mathrm{~h}$ at $298 \mathrm{~K}$ and calcined for $3 \mathrm{~h}$ in air at $623 \mathrm{~K}$.

Monometallic NiO samples were prepared by impregnation of the calcined support ( $3 \mathrm{~h}$, air, $623 \mathrm{~K})$ with the aqueous solution of $\mathrm{Ni}\left(\mathrm{NO}_{3}\right)_{2}$, corresponding to the pore volume of the support, followed by drying for $24 \mathrm{~h}$ at $298 \mathrm{~K}$ and calcining for $3 \mathrm{~h}$ in air at $623 \mathrm{~K}$ [15]. Bimetallic $\mathrm{NiO} /$ $\mathrm{Au} /$ supports and $\mathrm{Ag} / \mathrm{Pd} / \mathrm{Al}_{2} \mathrm{O}_{3}$ were produced by pore volume impregnation of fresh $\mathrm{Au} /$ supports and $\mathrm{Pd} / \mathrm{Al}_{2} \mathrm{O}_{3}$ with the aqueous solution of $\mathrm{Ni}\left(\mathrm{NO}_{3}\right)_{2}$ and $\mathrm{AgNO}_{3}$, respectively. The precursors obtained were dried for $24 \mathrm{~h}$ at $298 \mathrm{~K}$, and calcined for $3 \mathrm{~h}$ in air at $623 \mathrm{~K}$.

The metal contents in catalysts were determined by atomic absorption on a Thermo iCE 3000 AA spectrometer. The metals were preliminarily removed from the support by washing with aqua regia $\left(\mathrm{HCl} / \mathrm{HNO}_{3}=4: 1\right)$. The relative error of metal content determination was less than $1 \%$. Xray diffraction (XRD) patterns were accumulated with a Rigaku D/MAX 2500 instrument using $\mathrm{Cu} \mathrm{K}$ (a) radiation with a step size of $0.02^{\circ}$ two-theta $(2 \theta)$ over the range 35 $70^{\circ}$. Transmission electron microscopy (TEM) and energydispersive X-ray (EDX) analysis of catalysts were carried out on a JEOL JEM 2100F/UHR microscope with $0.1 \mathrm{~nm}$ resolution and a JED-2300 X-ray spectrometer, respectively. The size of spherical (SPH) and distorted (DIS) particles was calculated as diameter and maximum linear size, respectively. For each catalyst, 300-380 particles were processed to determine the particle size distribution. The average particle size was determined as the average size of the most frequent particles. The concentration of SPH particles in the sample was calculated as $\mathrm{C}(\mathrm{SPH})=n(\mathrm{SPH}) \times N \times$ $100 \%$, where $n(\mathrm{SPH})$ is the number of SPH particles, $N$ $(300-380)$ is the number of processed particles. The concentration of DIST particles was calculated in the same manner.

The hydrogenation of ethyne-ethene mixture was carried out using a fixed-bed flow reactor. A catalyst $(1 \mathrm{~g})$ was placed in a quartz reactor and heated to $357 \mathrm{~K}$ for $1 \mathrm{~h}$ in a stream of $\mathrm{H}_{2}$. The gas mixture containing $\mathrm{C}_{2} \mathrm{H}_{2}, \mathrm{H}_{2}$, and $\mathrm{C}_{2} \mathrm{H}_{4}$ in a 1:2:20 ratio was passed through the catalyst at a flow rate of $720 \mathrm{~h}^{-1}$. The reactor effluents were analyzed with Tcvet-800 gas chromatograph equipped with a flame ionization detector and a $30-\mathrm{m}$ PoropakT capillary column. The ethyne conversion was calculated as $\Delta\left(\mathrm{C}_{2} \mathrm{H}_{2}\right)=\left[\chi_{0}\left(\mathrm{C}_{2} \mathrm{H}_{2}\right)-\chi_{\mathrm{i}}\left(\mathrm{C}_{2} \mathrm{H}_{2}\right)\right] \times\left[\chi_{0}\left(\mathrm{C}_{2} \mathrm{H}_{2}\right)\right]^{-1} \times 100 \%$, where $\chi_{0}\left(\mathrm{C}_{2} \mathrm{H}_{2}\right)$ is the molar concentration of $\mathrm{C}_{2} \mathrm{H}_{2}$ in the initial gas mixture, and $\chi_{\mathrm{i}}\left(\mathrm{C}_{2} \mathrm{H}_{2}\right)$ is the molar concentration of $\mathrm{C}_{2} \mathrm{H}_{2}$ in the products after time on stream (i). The selectivity of the ethene formation was determined as $\mathrm{S}\left(\mathrm{C}_{2} \mathrm{H}_{4}\right)=\left[\left(\chi_{\mathrm{i}}\left(\mathrm{C}_{2} \mathrm{H}_{4}\right)-\chi_{0}\left(\mathrm{C}_{2} \mathrm{H}_{4}\right)\right] \times \Delta\left(\mathrm{C}_{2} \mathrm{H}_{2}\right)^{-1}\right.$, where $\chi_{0}\left(\mathrm{C}_{2} \mathrm{H}_{4}\right)$ and $\chi_{\mathrm{i}}\left(\mathrm{C}_{2} \mathrm{H}_{4}\right)$ are the molar concentrations of $\mathrm{C}_{2} \mathrm{H}_{4}$ in the initial gas mixture and in the products after reaction time (i), respectively; $\Delta\left(\mathrm{C}_{2} \mathrm{H}_{2}\right)$ is the ethyne conversion. The reproducibility of the catalytic measurements was $\pm 2 \%$ with respect to the absolute value of conversion and selectivity.

TOFs were calculated by equation TOF $=A \times B^{-1} \times t^{-1}$ as described in Mohr et al. and Okumura et al. [17, 18], where $[A]=[$ mole $]$ is the amount of ethyne converted per the reaction time $[t]=[h],[B]=[$ mole $]$ is the amount of the surface atoms in deposited clusters. $B$ was calculated as $\left(B_{\text {total }}(\mathrm{Au})+\right.$ $\left.B_{\text {total }}(\mathrm{Ni})\right) \times D$, where $B_{\text {total }}(\mathrm{Au})$ and $B_{\text {total }}(\mathrm{Ni})$ is the total moles of $\mathrm{Au}$ and $\mathrm{Ni}$ in the sample, respectively, $[D]$ is the surface-to-volume ratio for clusters with different average sizes given in Mohr et al. and Okumura et al. [17-19].

The calculations of $\mathrm{C}_{2} \mathrm{H}_{2}, \mathrm{C}_{2} \mathrm{H}_{4}$, and $\mathrm{H}_{2}$ adsorption on $\mathrm{Au}_{12}$ were performed within DFT framework using Perdow-Burke-Ernzerhof functional [20]. Relativistic effects of gold were taken into account in scalar-relativistic approach using Dirac-Coloumb-Breit Hamiltonian modified by Dyall [21]. The basis sets as implemented in the Priroda 06 program [22] were used in the calculations $(\mathrm{Au}$ $\{30 \mathrm{~s} 29 \mathrm{p} 20 \mathrm{~d} 14 \mathrm{f}\} /[8 \mathrm{~s} 7 \mathrm{p} 5 \mathrm{~d} 2 \mathrm{f}] ; \mathrm{H}\{6 \mathrm{~s} 2 \mathrm{p}\} /[2 \mathrm{~s} 1 \mathrm{p}] ; \mathrm{C}$ $\{10 \mathrm{~s} 7 \mathrm{p} 3 \mathrm{~d}\} /[3 \mathrm{~s} 2 \mathrm{p} 1 \mathrm{~d}]) . \mathrm{Au}_{12}$ cluster was considered as a model. It has a dynamic structure [23] and co-exists in flat (two-dimensional (2D)) and three-dimensional (3D) structures that allowed us to study the dependence of adsorption properties on the structural features of gold particles.

The adsorption energy of $\mathrm{RH}$ molecule $\left(E_{\mathrm{ad}}(\mathrm{RH}), \mathrm{RH}=\right.$ $\left.\mathrm{C}_{2} \mathrm{H}_{2}, \mathrm{C}_{2} \mathrm{H}_{4}, \mathrm{H}_{2}\right)$ on $\mathrm{Au}_{12}$ was calculated as $E_{\mathrm{ad}}(\mathrm{RH})=E$ $\left(\mathrm{Au}_{12}\right)+E(\mathrm{RH})-E\left(\mathrm{Au}_{12} \mathrm{RH}\right)$, where $E\left(\mathrm{Au}_{12}\right)$ is the total 
energy of an isolate gold cluster, $E(\mathrm{RH})$ is the total energy of isolate hydrocarbon, $E\left(\mathrm{Au}_{12} \mathrm{RH}\right)$ is the total energy of the hydrocarbon absorbed on $\mathrm{Au}_{12}$. All the total energies included zero-point vibration energies. The heats of adsorption $(Q)$ were calculated at $298 \mathrm{~K}$ on the basis of the formulas of statistical thermodynamics in the approximation of rigid rotato-harmonic oscillator. The calculation of all the structures was performed in singlet ground state. The types of stationary points on the potential energy surface were determined from the analysis of Hess matrix; the second derivatives were calculated analytically [23].

\section{Results and discussion}

In the present work, some $M / X$ catalysts $(M=\mathrm{Au}, \mathrm{NiO}, \mathrm{NiO} /$ $\mathrm{Au} ; X=\mathrm{Al}_{2} \mathrm{O}_{3}, \mathrm{TiO}_{2}, \mathrm{ZnO}, \mathrm{ZrO}_{2}$ ) numbered from №1 to №12 and reference $\mathrm{Ag} / \mathrm{Pd} / \mathrm{Al}_{2} \mathrm{O}_{3}$ catalyst ([Pd]= 0.021 wt. $\%$; $[\mathrm{Ag}]=0.006$ wt. $\%$ ) were synthesized. The actual metal loadings in the samples №s 1-12 are presented in Table 1. The actual gold content in the samples prepared by deposition-precipitation was $0.018-0.024 \mathrm{wt} . \%$ that is lower than theoretical loading. The loss of gold is attributed to washing treatment during the preparation [10]. The actual concentration of $\mathrm{Ni}$ in the impregnated samples was $0.006-$ $0.007 \mathrm{wt} . \%$ that is in agreement with theoretical weight percent. The molar ratio of $\mathrm{Ni} / \mathrm{Au}$ in bimetallic samples was close to the desired 1:1 ratio.

\section{The size and shape of supported $\mathrm{NiO}, \mathrm{Au}$, and $\mathrm{NiO} / \mathrm{Au}$ particles}

The structural features of supported particles in the samples №s 1-12 are presented in Figs. 1, 2, 3, and 4 and Table 1.
The particle size distributions in Ni samples were monomodal (see Fig. 1 as representative). The sizes of detectable nickel particles varied from 2 to $17 \mathrm{~nm}$ (Table 1). The average particle size in $\mathrm{NiO} / \mathrm{Al}_{2} \mathrm{O}_{3}, \mathrm{NiO} / \mathrm{TiO}_{2}, \mathrm{NiO} / \mathrm{ZnO}$, and $\mathrm{NiO} / \mathrm{ZrO}_{2}$ was $3,4.5,7$, and $7 \mathrm{~nm}$, respectively (Table 1). The increase in particle size of $\mathrm{NiO}$ during transition from $\mathrm{Al}_{2} \mathrm{O}_{3}$ to $\mathrm{ZrO}_{2}$ could be caused by the decrease of the surface area of a support, which favors segregation of clusters during the calcination [3-5]. The shape of the $\mathrm{NiO}$ particles, deposited on $\mathrm{Al}_{2} \mathrm{O}_{3}$, was nearly spherical (Fig. 1). The similar shape was observed for $\mathrm{NiO}$ particles immobilized on $\mathrm{TiO}_{2}, \mathrm{ZnO}$, and $\mathrm{ZrO}_{2}$ (Table 1). The obtained results are in agreement with the shape of nickel particles immobilized by impregnation from the aqueous solution of $\mathrm{Ni}\left(\mathrm{NO}_{3}\right)_{2}$ [9].

The particle size distributions in $\mathrm{Au} / \mathrm{Al}_{2} \mathrm{O}_{3}$ (Fig. 2, №1) and monometallic gold samples №s 4, 7, and 10 were monomodal and varied from 2 to $23 \mathrm{~nm}$ (Table 1). The average particle size of $\mathrm{Au}$ in $\mathrm{Au} / \mathrm{Al}_{2} \mathrm{O}_{3}, \mathrm{Au} / \mathrm{TiO}_{2}, \mathrm{Au} /$ $\mathrm{ZnO}$, and $\mathrm{Au} / \mathrm{ZrO}_{2}$ was $2.5,8,10$, and $9 \mathrm{~nm}$, respectively. The shapes of the supported Au particles were spherical (Table 1) that is in agreement with the shape of Au particles on the same supports immobilized by deposition-precipitation from $\mathrm{HAuCl}_{4} \times$ aq $[10,24]$.

The deposition of $\mathrm{NiO}$ particles on the $\mathrm{Au}$ catalysts resulted in a broadening of particle size distribution (see Figs. 1, 2, and 3 and Table 1). The shift of the average particle size to higher values was detected in bimetallic samples in comparison with corresponding monometallic ones (Table 1). The observed trend could be caused by the formation of decorated $\mathrm{M}_{1} / \mathrm{M}_{2}$ clusters, whose sizes are larger than $\mathrm{M}_{1}$ and $\mathrm{M}_{2}[3-5,14]$. The presence of $\mathrm{NiO} / \mathrm{Au}$ particles in the bimetallic samples was confirmed by the TEM-EDX analysis. The TEM micrograph of the goldnickel catalyst and the EDX elemental maps of $\mathrm{Au}$ and $\mathrm{Ni}$
Table 1 The structural properties of supported particles $\mathrm{M}$ $(\mathrm{M}=\mathrm{Au}, \mathrm{NiO}, \mathrm{NiO} / \mathrm{Au})$ and synergistic gain (SG) on $\mathrm{NiO} / \mathrm{Au}$ particles

The synergistic gain on $\mathrm{NiO} / \mathrm{Au}$ clusters (SG) was calculated as differences between $\mathrm{TOF}_{\mathrm{NiO} / \mathrm{Au}}$ $-\mathrm{TOF}_{\mathrm{Au}}-\mathrm{TOF}_{\mathrm{NiO}}$ after $735 \mathrm{~min}$ of reaction

$L$ average particle size, $S P H$ spherical shape, DIS distorted (nonspherical) shape, TOF turnover frequency

\begin{tabular}{|c|c|c|c|c|c|c|c|c|c|}
\hline \multirow[t]{2}{*}{ № } & \multirow[t]{2}{*}{ Support } & \multirow{2}{*}{$\begin{array}{l}{[\mathrm{Au}]} \\
\text { wt.\% }\end{array}$} & \multirow{2}{*}{$\begin{array}{l}{[\mathrm{Ni}]} \\
\text { wt.\% }\end{array}$} & \multirow{2}{*}{$\begin{array}{l}\text { Sizes } \\
\mathrm{nm}\end{array}$} & \multirow{2}{*}{$\begin{array}{l}\mathrm{L} \\
\mathrm{nm}\end{array}$} & \multicolumn{2}{|c|}{ M shape, $\%$} & \multirow{2}{*}{$\begin{array}{l}\text { TOF } \\
\mathrm{h}^{-1}\end{array}$} & \multirow{2}{*}{$\begin{array}{l}\text { SG } \\
\mathrm{h}^{-1}\end{array}$} \\
\hline & & & & & & SPH & DIS & & \\
\hline 1 & \multirow[t]{3}{*}{$\mathrm{Al}_{2} \mathrm{O}_{3}$} & 0.018 & 0 & $2-6$ & 2.5 & 100 & 0 & 36 & \multirow[t]{3}{*}{1,466} \\
\hline 2 & & 0 & 0.006 & $3-10$ & 3 & 100 & 0 & 276 & \\
\hline 3 & & 0.018 & 0.006 & $2-13$ & 5 & 60 & 40 & 1,778 & \\
\hline 4 & \multirow{3}{*}{$\mathrm{TiO}_{2}$} & 0.02 & 0 & $4-12$ & 8 & 100 & 0 & 28 & \multirow[t]{3}{*}{1,147} \\
\hline 5 & & 0 & 0.006 & $4-17$ & 4.5 & 100 & 0 & 402 & \\
\hline 6 & & 0.02 & 0.006 & $3-25$ & 13 & 68 & 32 & 1,577 & \\
\hline 7 & \multirow[t]{3}{*}{$\mathrm{ZnO}$} & 0.024 & 0 & $3-18$ & 10 & 100 & 0 & 0 & \multirow[t]{3}{*}{563} \\
\hline 8 & & 0 & 0.006 & $2-16$ & 7 & 100 & 0 & 1,023 & \\
\hline 9 & & 0.024 & 0.007 & $3-23$ & 14 & 74 & 26 & 1,586 & \\
\hline 10 & \multirow[t]{3}{*}{$\mathrm{ZrO}_{2}$} & 0.021 & 0 & $2-21$ & 9 & 100 & 0 & 0 & \multirow[t]{3}{*}{569} \\
\hline 11 & & 0 & 0.006 & $3-12$ & 7 & 100 & 0 & 812 & \\
\hline 12 & & 0.021 & 0.006 & $2-28$ & 16 & 81 & 19 & 1,381 & \\
\hline
\end{tabular}




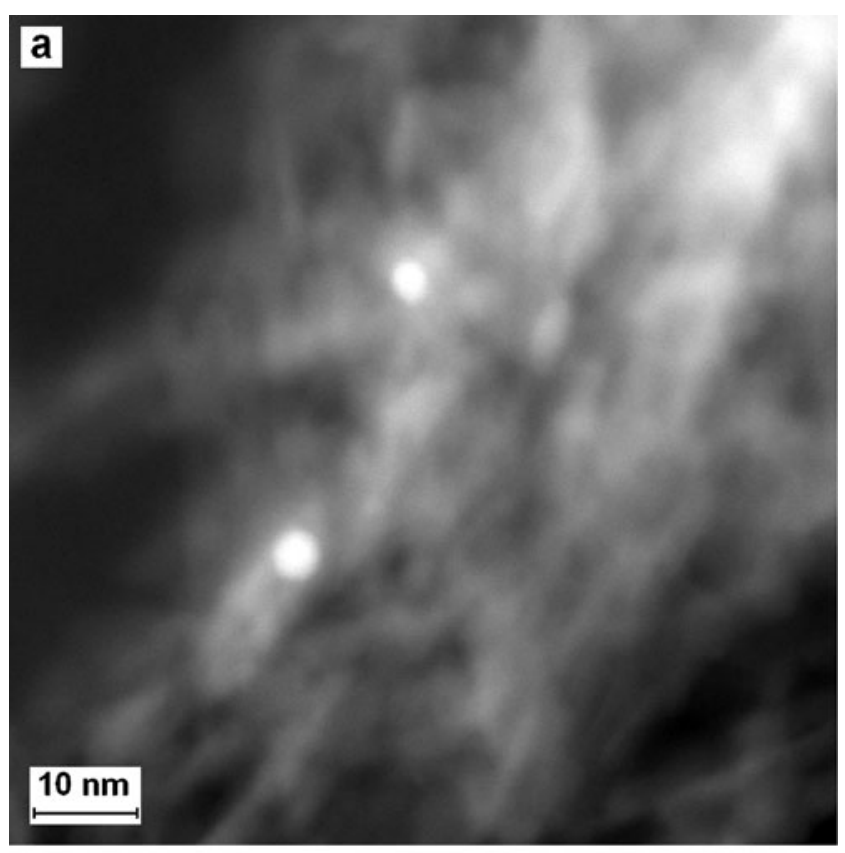

b

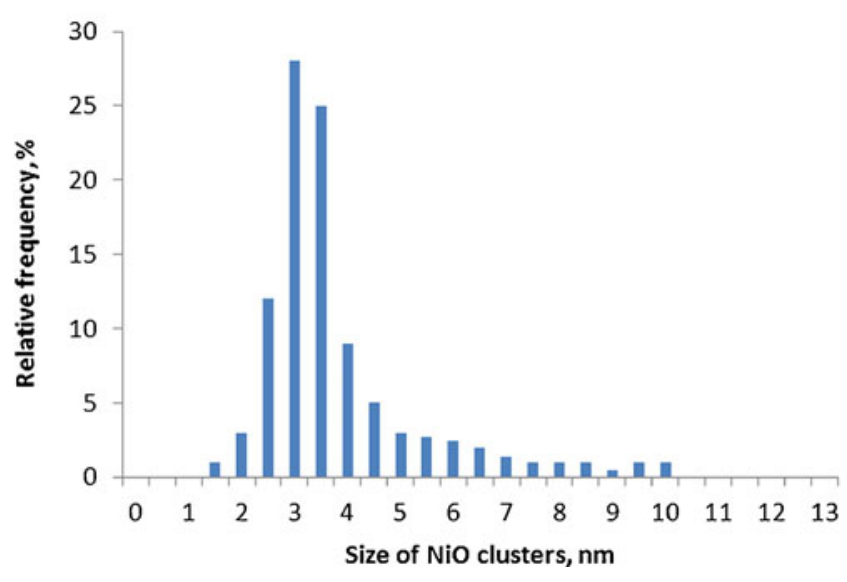

Fig. 1 TEM image of the $\mathrm{NiO} / \mathrm{Al}_{2} \mathrm{O}_{3}$ (a) and particle size distribution (b)

are presented in Fig. 4. The elemental maps of bimetallic sample contained individual particles of $\mathrm{Au}$ and $\mathrm{NiO}(\mathrm{Au}$ $\mathrm{M} \alpha$ and Ni $\mathrm{K} \alpha$ signals from these clusters do not overlap) along with mixed particles of $\mathrm{NiO} / \mathrm{Au}$ (overlay $\mathrm{Au} \mathrm{M} \alpha$ and Ni K $\alpha$ signals from the same particle).

The fraction of $\mathrm{NiO} / \mathrm{Au}$ particles in the bimetallic catalysts №s 3, 6, 9, and 12 ranged from $40 \%$ to $19 \%$ from the total number of supported particles. The size of $\mathrm{NiO} / \mathrm{Au}$ particles varied from 4 to $20 \mathrm{~nm}$, and the average size was always larger in comparison with $\mathrm{Au}$ and $\mathrm{NiO}$. An important feature of $\mathrm{NiO} / \mathrm{Au}$ clusters was their distortion (deviation from spherical shape) (see Fig. 4), which may be caused by the inclusion of $\mathrm{NiO}$ clusters into the surface of $\mathrm{Au}$ nanoparticles during the stage of catalyst preparation.
The catalytic properties of $\mathrm{NiO}, \mathrm{Au}$, and $\mathrm{NiO} / \mathrm{Au}$ nanocomposites

The conversion, selectivity, and durability of catalysts №s 1-12 tested in hydrogenation of ethyne-ethene mixture at $357 \mathrm{~K}$ are presented in Figs. 5, 6, and 7, the calculated TOFs are summarized in Table 1. After hydrogen treatment, $\mathrm{NiO}$ particles with size of 3-4.5 nm supported on $\mathrm{Al}_{2} \mathrm{O}_{3}$ and $\mathrm{TiO}_{2}$ showed 18-22\% ethyne conversion (Fig. 5). At these conversions, the selectivity to ethene on $\mathrm{NiO}$ catalysts was high-95-99\% that is in agreement with the results obtained in Zhang et al. [25]. The initial TOF of $\mathrm{NiO} /$ $\mathrm{Al}_{2} \mathrm{O}_{3}$ and $\mathrm{NiO} / \mathrm{TiO}_{2}$ was 497 and $608 \mathrm{~h}^{-1}$, respectively (Table 1). The TOFs of $3 \mathrm{~nm} \mathrm{NiO}$ particles are lower by

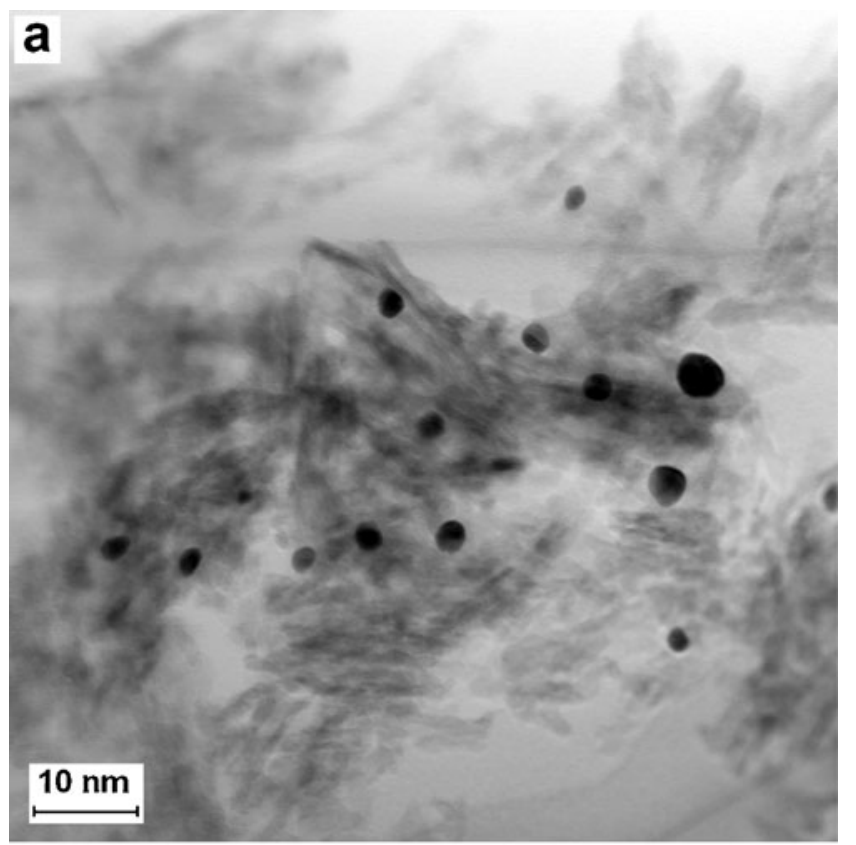

b

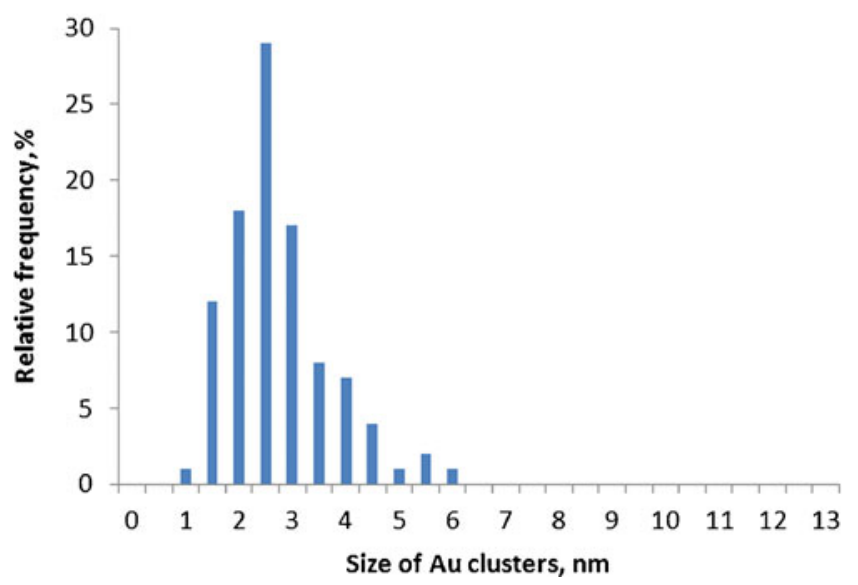

Fig. 2 TEM image of the $\mathrm{Au} / \mathrm{Al}_{2} \mathrm{O}_{3}$ (a) and particle size distribution (b) 

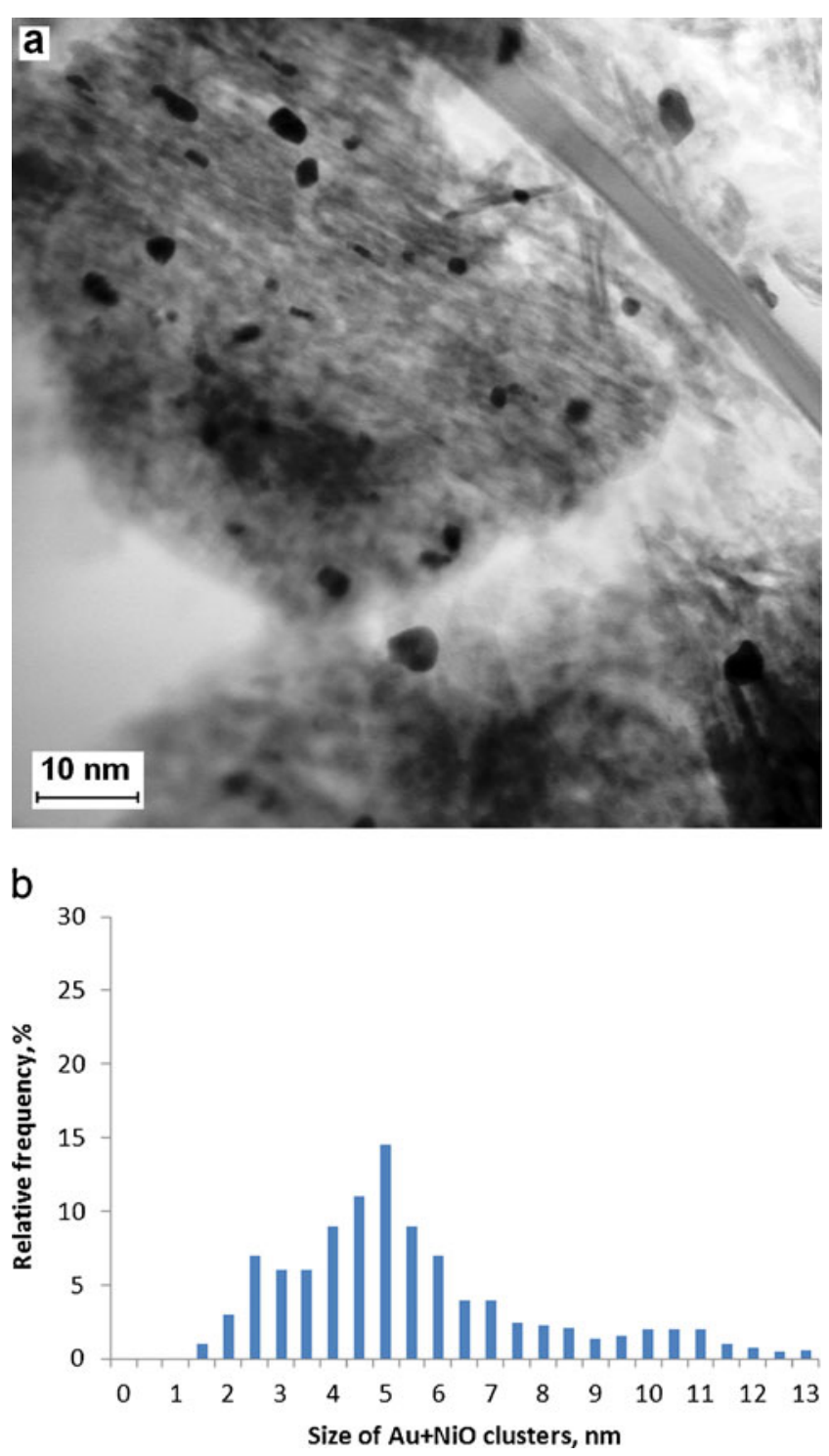

Fig. 3 TEM images of the $\mathrm{NiO} / \mathrm{Au} / \mathrm{Al}_{2} \mathrm{O}_{3}$ (a) and particle size distribution (b)

one to two orders of magnitude in comparison with $\mathrm{C} \equiv \mathrm{C}$ bond hydrogenation activity of 3-10 nm clusters of Pt [26] and $\mathrm{Ag} / \mathrm{Pd}$ [25] supported on $\mathrm{Al}_{2} \mathrm{O}_{3}$.

The $7 \mathrm{~nm} \mathrm{NiO}$ particles supported on $\mathrm{ZnO}$ and $\mathrm{ZrO}_{2}$ showed better activity in comparison with $3-4.5 \mathrm{~nm} \mathrm{NiO}$ particles supported on $\mathrm{Al}_{2} \mathrm{O}_{3}$ and $\mathrm{TiO}_{2}$ (Table 1). The negative-size effect of activity is the known feature of $\mathrm{Pd}$, $\mathrm{Pt}$, and $\mathrm{Ni}$ catalysts attributed to irreversible adsorption of unsaturated compounds on small clusters [3, 4, 10]. According to data presented in del Angel et al. [26], the TOF of Pt and Pd clusters decreases from 780 to 480 and from 9,910 to $8,640 \mathrm{~h}^{-1}$ as the cluster size decreases from 12 to 3 and from 10 to $3 \mathrm{~nm}$, respectively. The reason of the better activity of larger $\mathrm{NiO}$ particles can also be influenced by their reducibility. The rate-determining step in hydrogenation is usually a dissociative adsorption of $\mathrm{H}_{2}$ that takes place at $\mathrm{Ni}^{0}$ sites not at $\mathrm{Ni}^{2+}$ [4]. Keane and Medina showed that large $\mathrm{NiO}$ clusters are reduced much easier to $\mathrm{Ni}^{0}$ in comparison with small $\mathrm{NiO}$ clusters that strongly interact with surface groups of the support $[9,27]$. Therefore, the $7 \mathrm{~nm} \mathrm{NiO}$ of the sample №s 8 and 11 possess higher activity in hydrogenation in comparison with the 3 and $4.5 \mathrm{~nm} \mathrm{NiO}$ of the sample № 3 and № 5 (Table 1).

The stability of supported $\mathrm{NiO}$ clusters was low (Fig. 5). After 735 min of the reaction, the color of $\mathrm{NiO} / \mathrm{Al}_{2} \mathrm{O}_{3}$ and $\mathrm{NiO} / \mathrm{TiO}_{2}$ became darker, and TOFs decreased by approximately $55 \%$ and $49 \%$, respectively. The same trends were observed for $\mathrm{NiO} / \mathrm{ZnO}$ and $\mathrm{NiO} / \mathrm{ZrO}_{2}$ (Fig. 5). The most probable mechanism of nickel deactivation is due to green-oil formation as described in Borodziński et al. and Nikolaev et al. [3, 4].

A $1.5 \%$ conversion of ethyne with $100 \%$ selectivity to ethene was detected on $2.5 \mathrm{~nm}$ Au deposited on $\mathrm{Al}_{2} \mathrm{O}_{3}$ (Fig. 6). The high selectivity of $\mathrm{Au} / \mathrm{Al}_{2} \mathrm{O}_{3}$ is in agreement with results of Jia [28] and Gluhoi [29] reported that ethyne was hydrogenated to ethene on $\mathrm{Au} / \mathrm{Al}_{2} \mathrm{O}_{3}$ with $100 \%$ selectivity at $313-523 \mathrm{~K}$. The initial TOF for $2.5 \mathrm{~nm}$ Au was $36 \mathrm{~h}^{-1}$ that is in agreement with gold hydrogenation activity $[1,13,15,18]$ and lower in comparison with the activity of either NiO (Table 1) or Pt and Pd clusters of the same size deposited on alumina [26, 30].

The positive-size effect of activity was found for gold catalysts. As the size of gold decreases from 8 to $2.5 \mathrm{~nm}$, the initial TOF increases from 28 to $36 \mathrm{~h}^{-1}$ (Table 1). The better hydrogenation activity of $2.5 \mathrm{~nm}$ gold particles can be explained if the chemisorption of $\mathrm{H}_{2}$ is dependent on gold particle size. Our recent research on the TOF of Au particles of different sizes $(2-30 \mathrm{~nm})$ in hydrogenation of ethynylbenzene [13] and studies by Bus [30, 31], Serna [32], Boronat [33], and Jia [28] have proved the positive influence of small gold clusters on hydrogenation rate. It was concluded that $\mathrm{H}_{2}$ is dissociatively adsorbed only at the corners and edges of the supported gold particles [34, 35]. Gold atoms at the corner and edge sites have a low coordination number compared with face atoms and thus have a more reactive d-band, resulting in these atoms to be able to interact more easily with $\mathrm{H}_{2}$ [30] and facilitate the $\mathrm{H}_{2}$ dissociation.

It is interesting to note that almost identical $8-10 \mathrm{~nm} \mathrm{Au}$ clusters supported on $\mathrm{ZrO}_{2}, \mathrm{ZnO}$, and $\mathrm{TiO}_{2}$ possess different hydrogenation properties. Whereas $\mathrm{Au} / \mathrm{ZrO}_{2}$ and $\mathrm{Au} / \mathrm{ZnO}$ are inactive, $\mathrm{Au} / \mathrm{TiO}_{2}$ converts $0.5 \%$ of ethyne into ethene. It seems that the higher hydrogenation activity of $\mathrm{Au} / \mathrm{TiO}_{2}$ is due to specific metal-support interaction. Fujitani [36] find no $\mathrm{HD}$ formation between $\mathrm{H}_{2}$ and $\mathrm{D}_{2}$ other than on $\mathrm{Au} /$ $\mathrm{TiO}_{2}$. No HD formation was observed at any single-crystal surface ( $\mathrm{Au}(111), \mathrm{Au}(311)$, and $\left.\mathrm{TiO}_{2}(110)\right)$. This suggests that the bulk gold and $\mathrm{TiO}_{2}(110)$ surface did not make $\mathrm{H}_{2}$ dissociate, whereas the $\mathrm{Au} / \mathrm{TiO}_{2}$ surface did. Recent DFT 
Fig. 4 TEM image of the $\mathrm{NiO} /$ $\mathrm{Au} / \mathrm{Al}_{2} \mathrm{O}_{3}$ (a); EDX elemental maps of the $\mathrm{Au} \mathrm{M} \alpha(\mathbf{b})$ and $\mathrm{Ni}$ $\mathrm{K} \alpha(\mathbf{c})$ and typical TEM images of the $\mathrm{NiO} / \mathrm{Au}$ particles
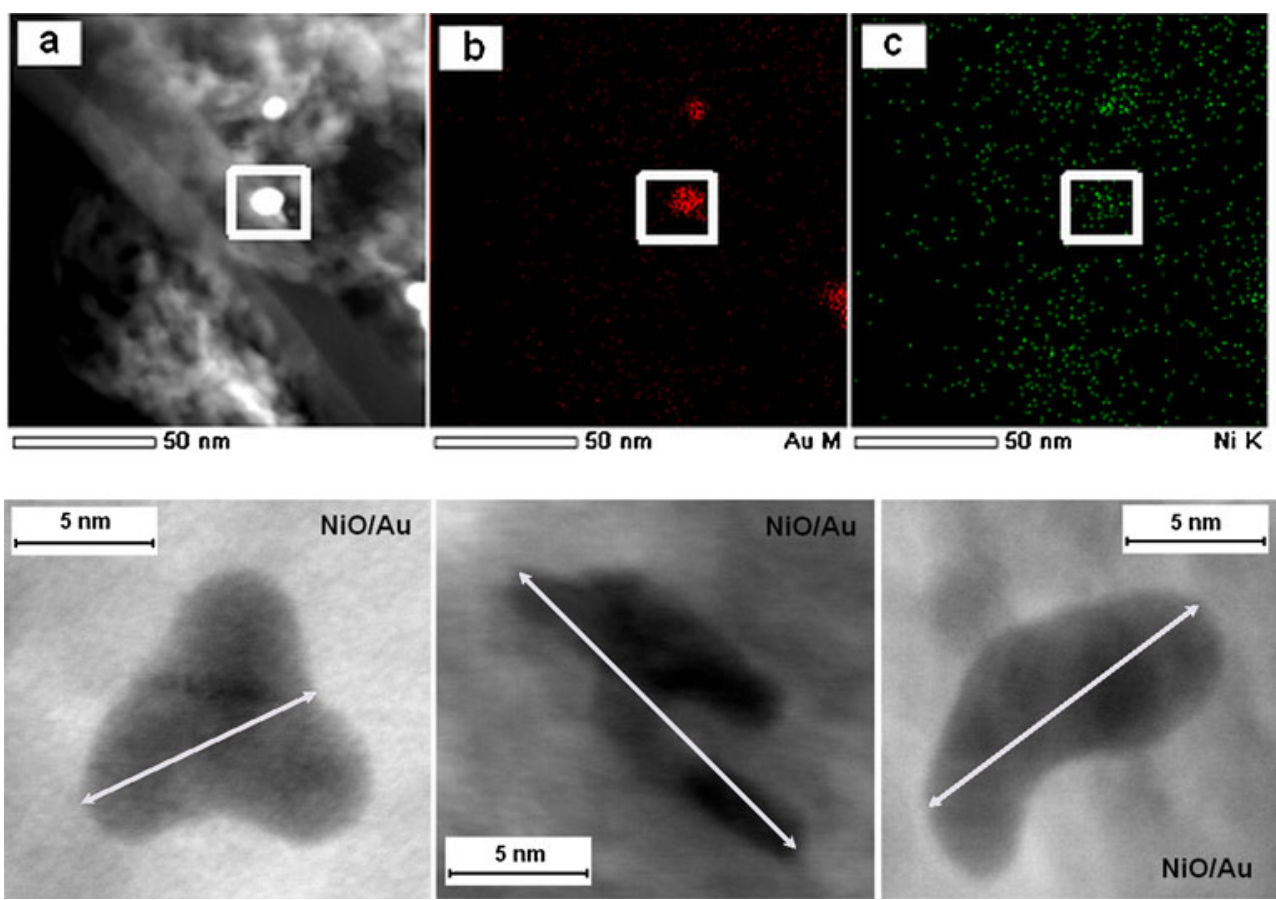

study [37] proved this phenomenon. Yong revealed the favored heterolytic dissociation of $\mathrm{H}_{2}$ with $E_{\mathrm{a}}=0.37 \mathrm{eV}$ at the perimeter sites of $\mathrm{Au} / \mathrm{TiO}_{2}$, where Au atom and a nearby surface $\mathrm{O}_{(\mathrm{s})}{ }^{2-}$ were involved. As a result of this process, oxygen atoms near the perimeter were passivated. Further $\mathrm{H}_{2}$ dissociation occurred on pure gold atoms via a homolytic mode with $E_{\mathrm{a}}=0.64 \mathrm{eV}$ [37].

Some contribution to the observed decreasing of TOFs in the row $\mathrm{Au} / \mathrm{Al}_{2} \mathrm{O}_{3}>\mathrm{Au} / \mathrm{TiO}_{2}>\mathrm{Au} / \mathrm{ZnO}>\mathrm{Au} / \mathrm{ZrO}_{2}$ (Table 1) could be provided by $\mathrm{OH}$ groups and metal cations of the supports. Thus, Zhang reported that dehydroxylated $\mathrm{Au} /$ $\mathrm{ZrO}_{2}$ was inactive in semi-hydrogenation of 1,3-butadiene but became active after regeneration of the surface $-\mathrm{M}-\mathrm{O}-$

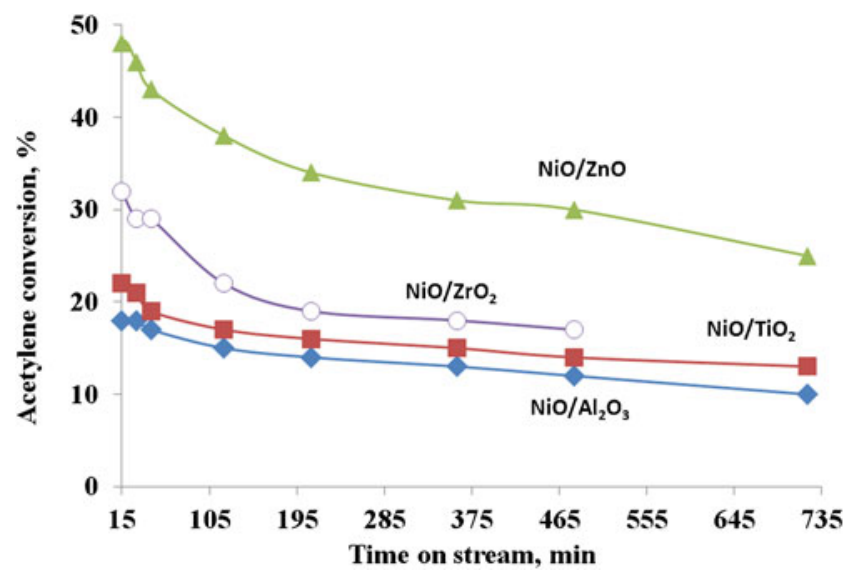

Fig. 5 Hydrogenation of ethyne-ethene mixture at $357 \mathrm{~K}$ over $\mathrm{NiO}$ catalysts № 2, 5, 8, 11. The metal loading of $\mathrm{Ni}$ in samples is 0.006 wt.\%
M- groups by water treatment [38]. Hydroxyl groups on $\mathrm{ZrO}_{2}$ were proposed to supply protons for hydrogenation and according to H/D exchange reactions between $D_{2}$ and the $-\mathrm{OH}$ groups occurred at above $323 \mathrm{~K}$ [38]. The specific surface of supports decreases in the row $\mathrm{Al}_{2} \mathrm{O}_{3}>\mathrm{TiO}_{2}>\mathrm{ZnO}$ $>\mathrm{ZrO}_{2}$, thus the concentration of hydroxyl groups in $\mathrm{Au}$ catalysts decreases during the transition from $\mathrm{Al}_{2} \mathrm{O}_{3}$ to $\mathrm{ZrO}_{2}$. As a result, the positive contribution of hydrogen from hydroxyl groups to the hydrogenation decreases.

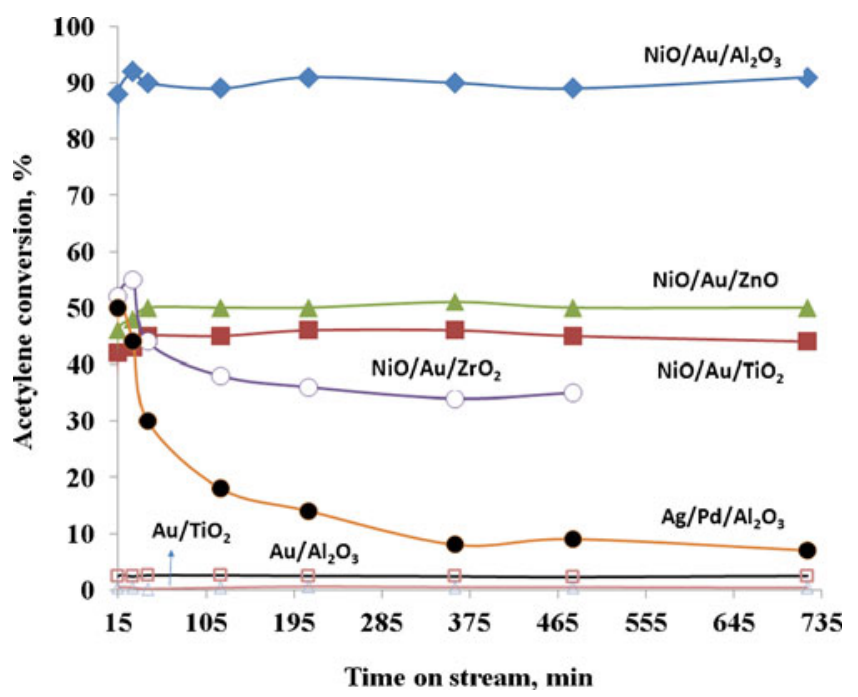

Fig. 6 Hydrogenation of ethyne-ethene mixture at $357 \mathrm{~K}$ over $\mathrm{Au}$ catalysts № 1, 3, 4, 6, 9, 12 and $\mathrm{Ag} / \mathrm{Pd}$ catalyst. The metal loadings of Pd and $\mathrm{Ag}$ are 0.021 and 0.006 wt.\%, respectively. The metal loadings of $\mathrm{Au}$ and $\mathrm{Ni}$ are $0.018-0.02$ wt.\% and $0.006-0.007$ wt.\%, respectively 


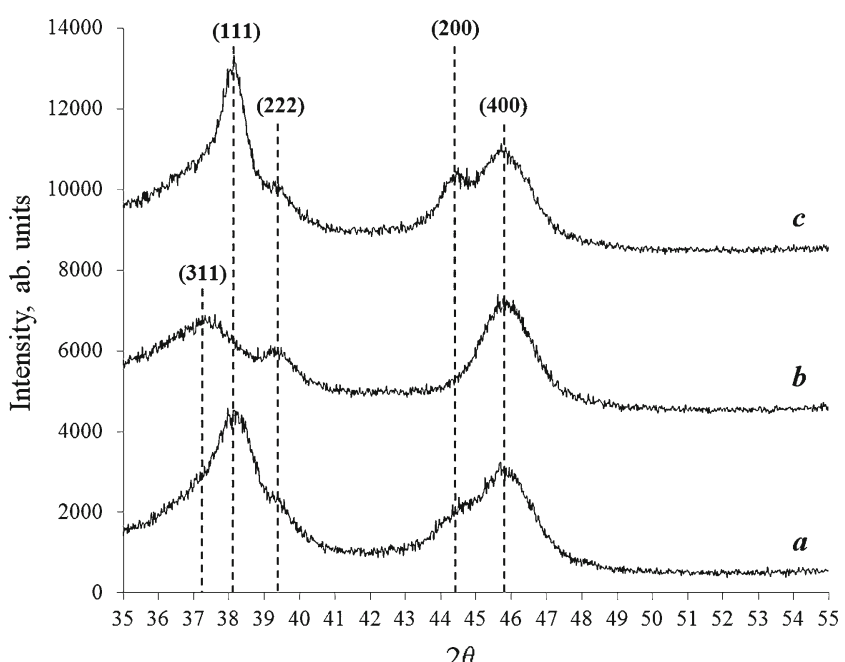

$2 \theta$

Fig. 7 Powder X-ray diffraction patterns for a $0.21 \% \mathrm{Au} / \mathrm{Al}_{2} \mathrm{O}_{3}$, b $0.15 \% \mathrm{Ni} / \mathrm{Al}_{2} \mathrm{O}_{3}$, and c $0.21 \% \mathrm{Au}+0.21 \% \mathrm{Ni} / \mathrm{Al}_{2} \mathrm{O}_{3}$. Planes (111), (200) are attributed to gold clusters. Planes (311), (222), (400) are attributed to alumina support

The metal cations of the supports are of importance in the adsorption and activation of reactants [39, 40]. It was suggested that cooperation of coordinatively unsaturated $\mathrm{Au}$ atoms and the acid-base pair site $\left(\mathrm{Al}^{\delta+}-\mathrm{O}^{\delta^{-}}\right)$play an important role as in $\mathrm{H}_{2}$ dissociation step and preferential adsorption of hydrogenated group [39]. Alumina is the oxide with strong Lewis acid sites that able to activate the $\mathrm{C}-\mathrm{H}$ bond of ethyne directly on the $\mathrm{M}^{\delta+}-\mathrm{O}^{\delta-}$ pairs [40]. A decrease in the Lewis coordinative activity was found for the metal cation of basic oxides $(\mathrm{CaO}, \mathrm{ZnO}$, and $\mathrm{MgO})$. The weakening of Lewis acid sites decreases the ability to form the acetylide species $\left(\mathrm{ZrO}_{2}\right)$ up to the full inactivity $\left(\mathrm{SiO}_{2}\right)$.

The durability of active $\mathrm{Au} / \mathrm{TiO}_{2}$ and $\mathrm{Au} / \mathrm{Al}_{2} \mathrm{O}_{3}$ catalysts was higher in comparison with nickel samples: No decrease in conversion occurred during 735 min (Figs. 5 and 6). The high durability of gold catalysts in hydrogenation of ethyne at $357 \mathrm{~K}$ is in good agreement with results of Jia [28], Zhang [38], and Azizi [41]. For example, Azizi and co-workers investigated the hydrogenation of ethyne and the formation of carbonaceous deposits using $\mathrm{Au} / \mathrm{CeO}_{2}$. The catalysts were prepared by direct anionic exchange, which produced catalysts with an average gold particle size of $2 \mathrm{~nm} . \mathrm{H}_{2} /$ $\mathrm{C}_{2} \mathrm{H}_{2}$ ratios between 3 and 60 were tested in the temperature range $300-673 \mathrm{~K}$. An ethene selectivity of $100 \%$ was observed for all $\mathrm{H}_{2} / \mathrm{C}_{2} \mathrm{H}_{2}$ ratios up to $573 \mathrm{~K}$. Above $573 \mathrm{~K}$, the deactivation occurred swiftly and was accompanied by the decreased selectivity.

The decoration of $\mathrm{Au}$ by $\mathrm{NiO}$ led to a sharp increase in ethyne conversion up to $90 \%$ while the selectivity still remains $100 \%$, and the time of stable operation remains at least 735 min (Fig. 6). Moreover, the activity and stability of $\mathrm{NiO} / \mathrm{Au}$ catalysts at $357 \mathrm{~K}$ were found to be higher than the activity and stability of reference $\mathrm{Ag} / \mathrm{Pd}$ catalyst for selective hydrogenation prepared by the same method as $\mathrm{NiO} / \mathrm{Au}$ catalyst (Fig. 6). The conversion of ethyne on $\mathrm{NiO} / \mathrm{Au}$ catalysts was higher than the sum of conversions on $\mathrm{NiO}$ and $\mathrm{Au}$ catalysts (Fig. 6) that points out the synergistic activity of $\mathrm{NiO} / \mathrm{Au}$ catalysts. The synergistic gain on $\mathrm{NiO} / \mathrm{Au}$ clusters (SG) after $735 \mathrm{~min}$ of time on stream was 1,466; 1,147 ; 563 ; and $569 \mathrm{~h}^{-1}$ for $\mathrm{NiO} / \mathrm{Au} / \mathrm{Al}_{2} \mathrm{O}_{3}, \mathrm{NiO} / \mathrm{Au} /$ $\mathrm{TiO}_{2}, \mathrm{NiO} / \mathrm{Au} / \mathrm{ZnO}$, and $\mathrm{NiO} / \mathrm{Au} / \mathrm{ZrO}_{2}$, respectively (Table 1).

The synergistic effects of activity resulted from the interaction between $M_{1}$ and $M_{2}$ metals can be attributed to the formation of alloy [3, 5, 8, 14, 42]. Besenbacher observed the formation of $\mathrm{Au}-\mathrm{Ni}$ alloy in $\mathrm{Au}-\mathrm{Ni} / \mathrm{MgAl}_{2} \mathrm{O}_{4}$ catalyst with extremely high metal loading $(\mathrm{Au}+\mathrm{Ni}=17 \mathrm{wt} . \%)$ after reduction at $823 \mathrm{~K}$ [14]. The obtained catalyst possessed the enhanced catalytic properties in $n$-butane steam-reforming. Zhang prepared $\mathrm{Au}_{7} \mathrm{Ni}_{3}$ intermetallic alloy by melting the mixture of gold and nickel at 1,333 K [42]. This alloy exhibited the synergistic activity in electro-oxidation of formic acid. It was reported that, compared with the standard spectrum of pure $\mathrm{Au}$, the diffraction angles of $\mathrm{Au}-\mathrm{Ni}$ sample were shifted to the higher positions, reflecting $\mathrm{Au}-\mathrm{Ni}$ alloy with lattice contraction due to the partial substitution of $\mathrm{Au}$ by $\mathrm{Ni}$ [42]. The attempts to obtain the XRD reflexes from supported metals of the sample №s 1-12 were failed due to the low concentration of gold (0.018-0.024 wt.\%) and/or nickel (0.006-0.007 wt.\%). The XRD patterns of specially prepared samples with relatively high metal contents $(0.15-0.42$ wt.\%) are presented in Fig. 7. The XRD pattern of $\mathrm{NiO} / \mathrm{Au}$ sample $(\mathrm{Au}=\mathrm{Ni}=0.21$ wt.\%) was described by the sum of XRD patterns of the gold and nickel catalysts (Fig. 7). No new reflexes or shifts of $\mathrm{Au}$ reflexes toward larger values pointed at alloy formation, as described in Lijuan et al. [42], were detected. The obtained XRD results allowed us to exclude the formation of new $\mathrm{Au}-\mathrm{Ni}$ compounds in our samples with a high degree of certainty. Moreover, the synthesis of $\mathrm{Au}-\mathrm{Ni}$ alloy [14, 42] was carried out at $823-1333 \mathrm{~K}$ and high metal contents (17-100 wt.\%). Thus, alloy formation is not possible at the temperatures and metal loadings employed in our study.

The synergism in $\mathrm{M}_{1}-\mathrm{M}_{2}$ activity also can be attributed to the formation of the new structural sites. For example, Keane linked the increase of the rate of 2,4-dichlorophenol hydrodeclorination on $\mathrm{Au} / \mathrm{Ni} / \mathrm{Al}_{2} \mathrm{O}_{3}$ with decoration of nickel clusters with gold ones [9]. It was proposed that the Au component served to adsorb and activate the $\mathrm{C}-\mathrm{Cl}$ bond whereas the $\mathrm{H}_{2}$ dissociated at the $\mathrm{Ni}^{0}$. The addition of tin to the $\mathrm{Pt} / \mathrm{SiO}_{2}$ catalyst produced a remarkable positive shift in both the product distribution and TOF in the liquid-phase hydrogenation of unsaturated aldehyde to corresponding alcohols [43, 44]. The simultaneous increase in both activity and selectivity indicates the formation of a new type of mixed $\left(\mathrm{M}^{\mathrm{x}+}\right) /(\mathrm{Pt})^{0}$ clusters, different in nature when 


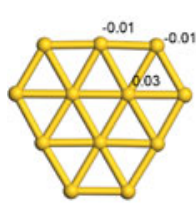

2D

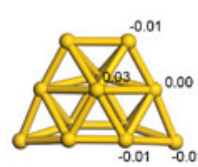

$3 \mathrm{D}$

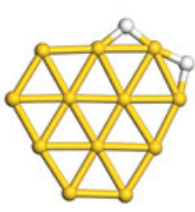

$\mathrm{Au}_{12} \mathrm{H}_{2}$

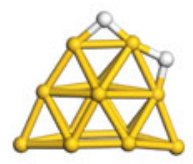

$\mathrm{Au}_{12} \mathrm{H}_{2}$

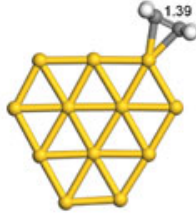

$\mathrm{Au}_{12} \mathrm{C}_{2} \mathrm{H}_{4}$

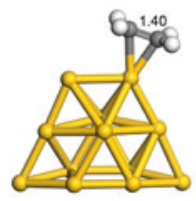

$\mathrm{Au}_{12} \mathrm{C}_{2} \mathrm{H}_{4}$

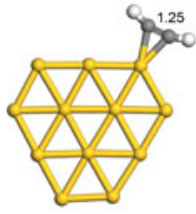

$\mathrm{Au}_{12} \mathrm{C}_{2} \mathrm{H}_{2}$

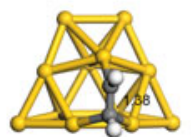

$\mathrm{Au}_{12} \mathrm{C}_{2} \mathrm{H}_{2}$
Fig. 8 The optimized structures of flat (2D) and three-dimensional (3D) $\mathrm{Au}_{12}$ clusters and the most stable complexes of $\mathrm{Au}_{12}$ with hydrogen, ethene, and ethyne molecules

compared with the original $\mathrm{Pt}$ and $\mathrm{M}$ ones. The promotion effect was proposed due to a $\left(\mathrm{M}^{\mathrm{x}+}\right)$ activating the $\mathrm{C}=\mathrm{O}$ bond, which becomes easily hydrogenated. The building of mixed $\left(\mathrm{M}_{1}\right) /\left(\mathrm{M}_{2}\right)$ clusters is very similar to what is occurring in the well-known strong metal support interaction between reducible oxide support and deposited metal clusters $[1-5,10]$.

Our investigations of model $\mathrm{Au}, \mathrm{Ni} / \mathrm{Au}$, and $\mathrm{Ni}$ catalysts by XPS, DRIFT, and XAS techniques showed that nickel in both $\mathrm{Ni} / \mathrm{Au}$ and $\mathrm{Ni}$ catalysts exists as $\mathrm{NiO}$, gold in the $\mathrm{Au}$ catalyst exists as $\mathrm{Au}^{0}$ nanoclusters, whereas the $\mathrm{Au}^{0}$ nanoclusters co-exist with $\mathrm{Au}^{3+}$ cations in the $\mathrm{NiO} / \mathrm{Au}$ samples [7]. Then, the first probable explanation (I) of synergistic activity between $\mathrm{NiO}$ and $\mathrm{Au}$ in ethyne hydrogenation (Table 1) could be due to the electron transfer from the electron-rich $\mathrm{Au}^{0}$ particles to the electron-deficient $\mathrm{NiO}$ that give new $\mathrm{Au}^{\delta+}$ catalytic sites.

According to the TEM data of the present research, there is a new significant fraction of distorted $\mathrm{Au}$ structures in $\mathrm{NiO} / \mathrm{Au}$ catalysts (Table 1). Moreover, the concentration of distorted particles is correlated with SG values. It is known that the deviation from spherical shape of the particle led to increase in surface corners and edges [5]. Thus, the second explanation (II) of synergistic activity can be linked with the formation of new Au structural sites with a low coordination number in $\mathrm{NiO} / \mathrm{Au}$ clusters.

\section{The nature of Au activation in $\mathrm{NiO} / \mathrm{Au}$ clusters}

The DFT calculation of $\mathrm{H}_{2}, \mathrm{C}_{2} \mathrm{H}_{2}$ and $\mathrm{C}_{2} \mathrm{H}_{4}$ on flat $\mathrm{Au}_{12}$ (2D) and $\mathrm{Au}_{12}$ (3D) containing flat, corner and edge atoms, were performed to test the reasonability of the explanations (I) and (II). The optimized structures of the most stable (2D) and (3D) $\mathrm{Au}_{12}$ isomers are shown in Fig. 8. The calculated heats of adsorption of substrates are listed in Table 2.

The calculated heat $(Q)$ of dissociative adsorption of $\mathrm{H}_{2}$ on the flat $\mathrm{Au}_{12}{ }^{0}$ (2D) was equal to $40 \mathrm{~kJ} / \mathrm{mol}$ (Table 2). During transition to uncharged $\mathrm{Au}_{12}{ }^{0}$ (3D) structures that contain flat elements (planes) and structural defects (corners and edges), the $Q\left(\mathrm{H}_{2}\right)$ increases up to $78 \mathrm{~kJ} / \mathrm{mol}$. The obtained results confirmed the existing hypotheses on the positive impact of cluster defects to the activation of $\mathrm{H}_{2}[13$, $30,32-35]$ and are in agreement with explanation of $\mathrm{NiO} /$ Au synergy (II).

The presence of a positive charge on the $\mathrm{Au}_{12}$ (2D) and $\mathrm{Au}_{12}$ (3D) clusters led to an increase in the $Q\left(\mathrm{H}_{2}\right)$ by 23 and $2 \mathrm{~kJ} / \mathrm{mol}$, respectively (Table 2). These results are in good agreement with the results of Zhang et al. [45, 46]. This group used $\mathrm{Au} / \mathrm{ZrO}_{2}$ to investigate the effects of $\mathrm{Au}^{3+} / \mathrm{Au}^{0}$ ratio on 1,3-butadiene hydrogenation. It was reported that metallic $\mathrm{Au}^{0}$ atoms at the surface of the gold particles were not the only active catalytic sites and that isolated $\mathrm{Au}^{3+}$ ions were the most active $[45,46]$. The enhanced activation of $\mathrm{H}_{2}$ on charged gold could be explained by mechanism of $\mathrm{Au}_{\mathrm{n}}-\mathrm{H}_{2}$ formation. Recently, Gao and Lyalin in their DFT calculation [47] showed that $\mathrm{H}_{2}$ dissociates at the low coordinated corner $\mathrm{Au}$ atom with formation of the slightly bent $\mathrm{H}-\mathrm{Au}-\mathrm{H}$ bond. The main feature of the formation of this hydride structure is the catalytic oxidation-reduction cycle $\mathrm{M}^{\mathrm{n}} \rightarrow \mathrm{M}^{\mathrm{n}+2} \rightarrow \mathrm{M}^{\mathrm{n}}$. In the case of non-charged zero-valence gold nanoparticles, this cycle should look like $\left(\mathrm{Au}_{\mathrm{n}+1}\right)^{0} \rightarrow\left(\mathrm{Au}_{\mathrm{n}}\right) \mathrm{Au}^{+2} \rightarrow\left(\mathrm{Au}_{\mathrm{n}+1}\right)^{0}$. But these valence changes seem to be improbable for gold, as the typical gold oxidation states are $0,+1$, and +3 rather than +2 . However, if supported gold nanoparticles may carry a positive charge +3 or +1 , then a highly probable catalytic cycle with common gold valences will be obtained: $\left(\mathrm{Au}_{\mathrm{n}}\right) \mathrm{Au}^{+1} \rightarrow\left(\mathrm{Au}_{\mathrm{n}}\right) \mathrm{Au}^{+3} \rightarrow\left(\mathrm{Au}_{\mathrm{n}}\right) \mathrm{Au}^{+1}$.
Table 2 The calculated heats of adsorption $(Q)$ of $\mathrm{C}_{2} \mathrm{H}_{2}, \mathrm{C}_{2} \mathrm{H}_{4}$, $\mathrm{H}_{2}$ (kilojoules per mole) on the flat zero-valence $\mathrm{Au}_{12}{ }^{0}$ (2D), positively charged $\mathrm{Au}_{12}{ }^{+}$(2D), three-dimensional zero-valence $\mathrm{Au}_{12}{ }^{0}$ (3D), and threedimensional positively charged $\mathrm{Au}_{12}{ }^{+}(3 \mathrm{D})$ clusters

\begin{tabular}{|c|c|c|c|c|c|}
\hline \multirow[t]{2}{*}{$\mathrm{RH}$} & \multirow[t]{2}{*}{ Type of adsorption } & \multicolumn{2}{|c|}{$Q(\mathrm{RH})$ on $\mathrm{Au}_{12}{ }^{Z}(2 \mathrm{D})$} & \multicolumn{2}{|c|}{$Q(\mathrm{RH})$ on $\mathrm{Au}_{12}{ }^{Z}(3 \mathrm{D})$} \\
\hline & & $Z=0$ & $Z=+1$ & $Z=0$ & $Z=+1$ \\
\hline $\mathrm{H}_{2}$ & Dissociative & 40 & 63 & 78 & 80 \\
\hline $\mathrm{C}_{2} \mathrm{H}_{4}$ & $\pi$ Complex & 88 & 132 & 90 & 147 \\
\hline \multirow[t]{3}{*}{$\mathrm{C}_{2} \mathrm{H}_{2}$} & $\pi$ Complex & 75 & 113 & 73 & 129 \\
\hline & di- $\sigma$ Complex & 59 & 102 & 98 & 134 \\
\hline & Bridge complexes $(\perp$ and $\|)$ & - & - & $139 \perp$ & $172 \|$ \\
\hline
\end{tabular}


The adsorption of ethene on $\mathrm{Au}_{12}{ }^{0}$ (2D) was accompanied by the formation of $\pi$-complex with one of the atoms in the cluster, while the adsorption of ethyne can be realized through $\pi$ - and di- $\sigma$ bonding (Table 2). The adsorption of $\mathrm{C}_{2} \mathrm{H}_{4}$ on $\mathrm{Au}_{12}{ }^{0}$ (3D) occurred through the formation of $\pi$-complex, and $Q\left(\mathrm{C}_{2} \mathrm{H}_{4}\right)$ was slightly higher than $Q\left(\mathrm{C}_{2} \mathrm{H}_{4}\right)$ on $\mathrm{Au}_{12}{ }^{0}(2 \mathrm{D})$ (Table 2). The increase in the heat of adsorption was also detected for ethyne $\pi$-complex during transition from $\mathrm{Au}_{12}{ }^{0}$ (2D) to $\mathrm{Au}_{12}{ }^{0}$ (3D). It was also revealed that ethyne on $\mathrm{Au}_{12}{ }^{0}$ (3D) can form a new type of coordination - perpendicular $(\perp)$ and parallel (\|) bridges (Fig. 8), with the high heat of adsorption (Table 2). Our calculation trends are in good agreement with results obtained in Jia et al. and Segura [28, 48]. Jia et al. [28] have shown that, at $273 \mathrm{~K}$, the amount of ethyne adsorbed on 3.8-nm gold particles immobilized on $\mathrm{Al}_{2} \mathrm{O}_{3}$ was 18 times greater than that of ethene. Moreover, in contrast to ethene, adsorption of ethyne was irreversible. Segura [48] has demonstrated that 4-nm gold nanoparticles supported on $\mathrm{CeO}_{2}$ are extremely selective in the hydrogenation of $\mathrm{C} \equiv \mathrm{C}$ bond in ethyne-ethene mixtures. His DFT calculation shows that differences in binding energy $E_{\mathrm{b}}\left(\mathrm{C}_{2} \mathrm{H}_{2}\right)-\mathrm{E}_{\mathrm{b}}\left(\mathrm{C}_{2} \mathrm{H}_{4}\right)$ on flat $\mathrm{Au}_{19}{ }^{0}(2 \mathrm{D})$ surface and on $\mathrm{Au}_{19}{ }^{0}$ (3D) cluster are 0.08 and $0.66 \mathrm{eV}$, respectively. Segura attributed the high selectivity of gold to the preferential adsorption of $\mathrm{C} \equiv \mathrm{C}$ bond compared with $\mathrm{C}=\mathrm{C}$ bond at the edges of gold clusters. Thus, $\mathrm{Au}$ defects favor the selective ethyne adsorption and its further conversion.

Ethyne and ethene are Lewis bases sensitive to electron acceptors $[4,5,40]$. An increase in the surface positive charge on $\mathrm{Au}$ due to electron transfer [7] improves the electron acceptor properties of gold and thereby should lead to stronger adsorption of ethyne or ethene on $\mathrm{Au}^{\delta+}$ than on $\mathrm{Au}^{0}$ and, therefore, increase the probability of the chemical reaction. Table 2 shows that positive charge on the flat as well as on the $\mathrm{Au}_{12}{ }^{+}$(2D) and $\mathrm{Au}_{12}{ }^{+}$(3D) cluster leads to an increase in the heat of adsorption of ethene in $\pi$-complex up to 132 and $147 \mathrm{~kJ} / \mathrm{mol}$, respectively. Surprisingly, the calculated heats of adsorption of ethyne (113 and $102 \mathrm{~kJ} / \mathrm{mol}$ for $\pi$ - and di- $\sigma$ form, respectively) were smaller in comparison to the heat of adsorption of ethene on flat gold surface, but the positive impact to growth of heat of ethyne adsorption remained unchanged. Moreover, the heat of ethyne adsorption in the most stable (\|) bridge form on $\mathrm{Au}_{12}{ }^{+}$(3D) increased up to $172 \mathrm{~kJ} /$ mol, which is larger by $25 \mathrm{~kJ} / \mathrm{mol}$ in comparison with the heat of ethene adsorption on $\mathrm{Au}_{12}{ }^{+}$(3D). Thus, positive charge on $3 \mathrm{D}$ clusters of $\mathrm{Au}$ favors preferential ethyne adsorption and increases its further conversion.

\section{Conclusion}

Monometallic $\mathrm{Au}$ and $\mathrm{NiO}$ particles supported on $\mathrm{Al}_{2} \mathrm{O}_{3}$, $\mathrm{TiO}_{2}, \mathrm{ZnO}$, and $\mathrm{ZrO}_{2}$ possess $95-100 \%$ selectivity to ethene in hydrogenation of ethyne-ethene mixture at $357 \mathrm{~K}$.
The negative-size effect was revealed for $\mathrm{NiO}$ particles: As the size of $\mathrm{NiO}$ clusters decreases from 7 to $3 \mathrm{~nm}$, the TOF decreases from $812-1,023$ to $276 \mathrm{~h}^{-1}$. In contrast to $\mathrm{NiO}$, the size effect of activity was found to be positive for Au. As the size of gold decreases from 8 to $2.5 \mathrm{~nm}$, the TOF increases from $0-28$ to $36 \mathrm{~h}^{-1}$. The observed size trends of TOF result from different abilities of gold and nickel to adsorb and activate the ethyne, ethene, and hydrogen.

The bimetallic $\mathrm{NiO} / \mathrm{Au}$ catalysts possess $100 \%$ selectivity to ethene and higher activity and stability in comparison with mono- and bimetallic catalysts based on $\mathrm{Pd}, \mathrm{Ag}$, and $\mathrm{Ni}$. The decoration of $\mathrm{Au}$ by $\mathrm{NiO}$ led to increase in TOFs of $\mathrm{NiO} / \mathrm{Au}$ catalysts up to $1,778 \mathrm{~h}^{-1}$. The synergistic gain on $\mathrm{NiO} / \mathrm{Au}$ clusters calculated as $\mathrm{TOF}_{\mathrm{NiO} / \mathrm{Au}}-\mathrm{TOF}_{\mathrm{Au}}-\mathrm{TOF}_{\mathrm{NiO}}$ was 1,$466 ; 1,147 ; 563$; and $569 \mathrm{~h}^{-1}$ for $\mathrm{NiO} / \mathrm{Au} / \mathrm{Al}_{2} \mathrm{O}_{3}, \mathrm{NiO} /$ $\mathrm{Au} / \mathrm{TiO}_{2}, \mathrm{NiO} / \mathrm{Au} / \mathrm{ZnO}$, and $\mathrm{NiO} / \mathrm{Au} / \mathrm{ZrO}_{2}$, respectively. The formation of $\mathrm{Au}^{\delta+}$ in $\mathrm{NiO} / \mathrm{Au}$ particles and deviation of $\mathrm{NiO} / \mathrm{Au}$ clusters shape from the spherical were detected. Using the methods of quantum chemistry, it was shown that distorted 3D and/or positively charged gold structures favor a dissociative adsorption of $\mathrm{H}_{2}$ and preferential adsorption of ethyne from ethyne-ethene mixture.

Acknowledgments This work was supported by the Russian Foundation for Basic Research (Grant № 11-01-00280, № 10-03-00999, № 11-03-01011, and № 11-03-00403), the Russian Federation Ministry of Education and Science (State Contracts № 16.513.11.3137) and by the grants from the Russian Federation President (MK-107.2011.3, MK2917.2012.3, and MK-1621.2012.3).

Open Access This article is distributed under the terms of the Creative Commons Attribution License which permits any use, distribution and reproduction in any medium, provided the original author(s) and source are credited.

\section{References}

1. McEwan L, Julius M, Roberts S, Fletcher JCQ (2010) A review of the use of gold catalysts in selective hydrogenation reactions. Gold Bull 43:298-306. doi:10.1007/BF03214999

2. Hugon A, Delannoy L, Louis C (2008) Supported gold catalysts for selective hydrogenation of 1,3-butadiene in the presence of an excess of alkenes. Gold Bull 41:127-138. doi:10.1007/ BF03216590

3. Borodziński A, Bond GC (2008) Selective hydrogenation of ethyne in ethene-rich streams on palladium catalysts, part 2: steadystate kinetics and effects of palladium particle size, carbon monoxide, and promoters. Catal Rev Sci Eng 50:379-469. doi:10.1080/01614940802142102

4. Nikolaev SA, Zanaveskin LN, Smirnov VV, Averyanov VA, Zanaveskin KL (2009) Catalytic hydrogenation of alkyne and alkadiene impurities in alkenes. Practical and theoretical aspects. Russ Chem Rev 78:231-247. doi:10.1070/RC2009v078n03ABEH003893

5. Rostovshchikova TN, Lokteva ES, Nikolaev SA, Golubina EV, Gurevich SA, Kozhevin VM, Yavsin DA, Lunin VV (2011) New approaches to design of nanostructured catalysts. In: Song M (ed) Catalysis: principles, types and applications. Nova Science Publishers, New York, pp 245-306 
6. Grisel R, Weststrate K-J, Gluhoi A, Nieuwenhuys BE (2002) Catalysis by gold nanoparticles. Gold Bull 35:39-45. doi:10.1007/ BF03214836

7. Tkachenko OP, Kustov LM, Nikolaev SA, Smirnov VV, Klementiev $\mathrm{KV}$ et al (2009) DRIFT, XPS and XAS investigation of $\mathrm{Au}-\mathrm{Ni} / \mathrm{Al}_{2} \mathrm{O}_{3}$ synergetic catalyst for allylbenzene isomerization. Topics in Catalysis 52:344-350. doi:10.1007/s11244-008-9167-z

8. Hashmi A, Stephen K, Hutchings GJ (2006) Gold catalysis. Angew Chem Int Ed 45:7896-7936. doi:10.1002/anie.200602454

9. Keane MA, Gómez-Quero S, Cárdenas-Lizana F (2009) Aluminasupported $\mathrm{Ni}-\mathrm{Au}$ : surface synergistic effects in catalytic hydrodechlorination. Chem Cat Chem 1:270-278. doi:10.1002/cctc.200900070

10. Bond GC, Louis C, Thompson DT (2006) Catalysis by gold. Imperial College Press, London, $366 \mathrm{P}$

11. Simakova OA, Campo B, Murzin DY (2010) Gold on carbon catalysts. In: Chow PE (ed) Gold nanoparticles: preparation, characterization and fabrication. Nova Science Publishers, New York, pp 147-171

12. Lopez-Sanchez JA, Lennon D (2005) The use of titania- and iron oxide-supported gold catalysts for the hydrogenation of propyne. Appl Catal A 291:230-237. doi:10.1016/j.apcata.2005.01.048

13. Nikolaev SA, Smirnov VV (2009) Selective hydrogenation of phenylacetylene on gold nanoparticles. Gold Bull 42:182-189. doi:10.1007/BF03214932

14. Besenbacher F, Chorkendorff I, Clausen BS, Hammer B, Molenbroek AM, Nørskov JK, Stensgaard I (1998) Design of a surface alloy catalyst for steam reforming. Science 279:1913-1915. doi:10.1126/ science.279.5358.1913

15. Nikolaev SA, Smirnov VV (2009) Synergistic and size effects in selective hydrogenation of alkynes on gold nanocomposites. Catal Today 147S:S336-S341. doi:10.1016/j.cattod.2009.07.032

16. Haruta M (2004) Nano particulate gold catalysts for lowtemperature CO oxidation. J New Mat Elect Syst 7:163-172

17. Mohr C, Hofmeister H, Claus P (2003) The influence of real structure of gold catalysts in the partial hydrogenation of acrolein. J Catal 213:86-94. doi:10.1016/S0021-9517(02)00043-X

18. Okumura M, Akita T, Haruta M (2002) Hydrogenation of 1,3-butadiene and of crotonaldehyde over highly dispersed Au catalysts. Catal Today 74:265-269. doi:10.1016/S0920-5861(02)00034-2

19. Mohr C, Hofmeister H, Radnik J, Claus P (2003) Identification of active sites in gold-catalyzed hydrogenation of acrolein. J Am Chem Soc 125:1905-1911. doi:10.1021/ja027321q

20. Perdew JP, Burke K, Ernzerhof M (1996) Generalized gradient approximation made simple. Phys Rev Lett 77:3865-3868. doi:10.1103/PhysRevLett.77.3865

21. Visscher L (2002) Chapter 6. Post Dirac-Hartree-Fock methodselectron correlation. Theor and Comput Chem 11:291-331. doi:10.1016/S1380-7323(02)80032-2

22. Laikov DN (1997) Fast evaluation of density functional exchangecorrelation terms using the expansion of the electron density in auxiliary basis sets. Chem Phys Lett 281:151-156. doi:10.1016/ S0009-2614(97)01206-2

23. Mukhamedzyanova DF, Ratmanova NK, Pichugina DA, Kuz'menko NE (2012) A structural and stability evaluation of $\mathrm{Au}_{12}$ from an isolated cluster to the deposited material. J Phys Chem C 116:11507-11518. doi:10.1021/jp212367z

24. Claus P (2005) Heterogeneously catalysed hydrogenation using gold catalysts. Appl Catal A 291:222-229. doi:10.1016/ j.apcata.2004.12.048

25. Zhang Q, Li J, Liu X, Zhu Q (2000) Synergetic effect of Pd and $\mathrm{Ag}$ dispersed on $\mathrm{Al}_{2} \mathrm{O}_{3}$ in the selective hydrogenation of acetylene. Appl Catal A 197:221-228. doi:10.1016/S0926860X(99)00463-9

26. Del Angel G, Benitez JL (1993) Selective hydrogenation of phenylacetylene on $\mathrm{Pd} / \mathrm{Al}_{2} \mathrm{O}_{3}$ : effect of the addition of $\mathrm{Pt}$ and particle size. React Kinet Catal Lett 51:547-553. doi:10.1007/BF02069103
27. Medina F, Salagre P, Sueiras J-E, Fierro J-LG (1994) Characterization of several $\gamma$-alumina-supported nickel catalysts and activity for selective hydrogenation of hexanedinitrile. J Chem Soc Faraday Trans 90:1455-1459. doi:10.1039/FT9949001455

28. Jia J, Haraki K, Kondo JN, Domen K, Tamaru K (2000) Selective hydrogenation of acetylene over $\mathrm{Au} / \mathrm{Al}_{2} \mathrm{O}_{3}$ catalyst. J Phys Chem B 104:11153-11156. doi:10.1021/jp001213d

29. Gluhoi AC, Bakker JW, Nieuwenhuys BE (2010) Gold, still a surprising catalyst: selective hydrogenation of acetylene to ethylene over Au nanoparticles. Catal Today 154:13-20. doi:10.1016/ j.cattod.2010.02.021

30. Bus E, Prins R, van Bokhoven JA (2007) Origin of the cluster-size effect in the hydrogenation of cinnamaldehyde over supported Au catalysts. Catal Comm 8:1397-1402. doi:10.1016/j.catcom.2006.11.040

31. Bus E, Miller JT, van Bokhoven JA (2005) Hydrogen chemisorption on $\mathrm{Al}_{2} \mathrm{O}_{3}$-supported gold catalysts. J Phys Chem B 109:14581-14587. doi:10.1021/jp051660z

32. Boronat M, Concepción P, Corma A, González S, Illas F, Serna P (2007) A molecular mechanism for the chemoselective hydrogenation of substituted nitroaromatics with nanoparticles of gold on $\mathrm{TiO} 2$ Catalysts: a cooperative effect between gold and the support. J Am Chem Soc 129:16230-16237. doi:10.1021/ja076721g

33. Boronat M, Lllas F, Corma A (2009) Active sites for $\mathrm{H}_{2}$ adsorption and activation in $\mathrm{Au} / \mathrm{TiO}_{2}$ and the role of the support. J Phys Chem A 113:3750-3757. doi:10.1021/jp808271y

34. Boronat M, Concepción P, Corma A (2009) Unraveling the nature of gold surface sites by combining IR spectroscopy and DFT calculations. Implications in catalysis. J Phys Chem C 113:16772-16784. doi:10.1021/jp905157r

35. Kartusch C, van Bokhoven JA (2009) Hydrogenation over gold catalysts: the interaction of gold with hydrogen. Gold Bull 42:343348. doi:10.1007/BF03214957

36. Fujitani T, Nakamura I, Akita T, Okumura M, Haruta M (2009) Hydrogen dissociation by gold clusters. Angew Chem Int Ed 48:9515-9518. doi:10.1002/anie.200905380

37. Yong B, Cao X-M, Gong X-Q, Hu P (2012) A density functional theory study of hydrogen dissociation and diffusion at the perimeter sites of $\mathrm{Au} / \mathrm{TiO}_{2}$. Phys Chem Chem Phys 114:3741-3745. doi:10.1039/C2CP23755E

38. Zhang X, Shi H, Xu B-Q (2011) Vital roles of hydroxyl groups and gold oxidation states in $\mathrm{Au} / \mathrm{ZrO}_{2}$ catalysts for 1,3-butadiene hydrogenation. J Catal 279:75-87. doi:10.1016/j.jcat.2011.01.002

39. Shimizu K-i, Yamamoto T, Tai Y, Satsuma A (2011) Selective hydrogenation of nitrocyclohexane to cyclohexanone oxime by alumina-supported gold cluster catalysts. J Mol Catal A 345:5459. doi:10.1016/j.molcata.2011.05.018

40. Ivanov AV, Koklin AE, Uvarova EB, Kustov LM (2003) A DRIFT spectroscopic study of acetylene adsorbed on metal oxides. Phys Chem Chem Phys 5:4718-4723. doi:10.1039/ B307138C

41. Azizi Y, Petit C, Pitchon V (2008) Formation of polymer-grade ethylene by selective hydrogenation of acetylene over $\mathrm{Au} / \mathrm{CeO}_{2}$ catalyst. J Catal 256:338-344. doi:10.1016/j.jcat.2008.04.003

42. Lijuan Z, Tian Ruili HP, Yuru M, Dingguo X (2010) A gold-nickel alloy as anodic catalyst in a direct formic acid fuel cell. Rare Metal Mat Eng 39:945-948. doi:10.1016/S1875-5372(10) 60102-6

43. Merlo AB, Machado BF, Vetere V, Faria JL, Casella ML (2010) $\mathrm{PtSn} / \mathrm{SiO}_{2}$ catalysts prepared by surface controlled reactions for the selective hydrogenation of cinnamaldehyde. Appl Catal A 383:4349. doi:10.1016/j.apcata.2010.05.020

44. Coq B, Figueras F (2001) Bimetallic palladium catalysts: influence of the co-metal on the catalyst performance. J Mol Catal A 173:117-134. doi:10.1016/S1381-1169(01)00148-0 
45. Zhang X, Shi H, Xu B-Q (2005) Catalysis by gold: isolated surface $\mathrm{Au}^{3+}$ ions are active sites for selective hydrogenation of 1,3-butadiene over $\mathrm{Au} / \mathrm{ZrO}_{2}$ catalysts. Angew Chem Int Ed 44:7132-7135. doi:10.1002/anie.200502101

46. Zhang X, Shi H, Xu B-Q (2007) Comparative study of $\mathrm{Au} / \mathrm{ZrO}_{2}$ catalysts in $\mathrm{CO}$ oxidation and 1,3-butadiene hydrogenation. Catal Today 122:330-337. doi:10.1016/j.cattod.2007.02.016
47. Gao M, Lyalin A, Taketsugu T (2011) Role of the support effects on the catalytic activity of gold clusters: a density functional theory study. Catalysts 1:18-39. doi:10.3390/catal1010018

48. Segura Y, López N, Pérez-Ramírez J (2007) Origin of the superior hydrogenation selectivity of gold nanoparticles in alkyne+alkene mixtures: triple-versus double-bond activation. J Catal 247:383386. doi:10.1016/j.jcat.2007.02.019 